\title{
Společné, či oddělené vzdělávání dívek a chlapců? ${ }^{1}$
}

\author{
Irena Smetáčková \\ Univerzita Karlova, Pedagogická fakulta, Katedra psychologie
}

Redakci zasláno 31. 8. 2012 / upravená verze obdržena 22. 7. 2013 / k uveřejnění přijato 4. 9.2013

\begin{abstract}
Abstrakt: Článek porovnává dva základní vyučovací modely z hlediska zastoupení dívek a chlapců - koedukovanou a oddělenou výuku. S využitím zahraničních studií diskutuje pozitivní a negativní stránky obou modelů. Z hlediska genderové rovnosti ve vzdělávání se nereflektovaná koedukace jeví problematická, protože v jejím rámci může snadno docházet k prohlubování genderových stereotypů. Eventuální úvahy o zavedení oddělené výuky dívek a chlapců (po vzoru zahraničních experimentů) by měly zohledňovat žákovský pohled. Článek proto přináší výsledky dotazníkového šetření s účastí 556 žáků/yň 2. stupně základních škol, které mapovalo jejich postoje a zkušenosti s pobytem ve smíšených a oddělených skupinách. Šetření ukázalo, že děti preferují smíšené tř́ídy, avšak zároveň mají zkušenosti se vzájemným genderově motivovaným obtěžováním a genderově stereotypním zacházením ze strany vyučujících.
\end{abstract}

Klíčová slova: koedukace, genderově oddělená výuka, genderová rovnost

\section{Slabé a silné stránky koedukace}

V českých školách panuje od 20. let 20. století tradice koedukovaných tř́d. Jejich zavedení bylo považováno za významný krok $\mathrm{k}$ posílení rovnosti ve vzdělávání, protože společná výuka dívek a chlapců měla zaručovat, že budou vystaveni shodnému učivu i kritériím hodnocení. S koedukací je skutečně spojena řada výhod - jednak zaručuje formální rovnost v přístupu ke vzdělávání a rovnost v podmínkách výuky, ${ }^{2}$ jednak poskytuje větší pestrost

1 Článek vznikl v rámci projektu Nerovné podmínky škol - nerovné šance podpořené Grantovou agenturou ČR (číslo projektu: P407-11-1556).

2 V inspiraci pojetím rovnosti Colemana (1993) lze v mikroškolní dimenzi identifikovat tři základní typy vzdělávacích nerovností: (a) nerovný přístup dívek a chlapců k vyučovacím předmětům a aktivitám (u některých předmětů či aktivit se předpokládá větší účast jedné ze skupin), (b) nerovné implicitní podmínky výuky (očekávání a způsob komunikace s dívkami a chlapci se liší navzdory deklarované genderové neutralitě školy), (c) nerovné vzdělávací výsledky (průměrné výsledky dívek a chlapců se liší, aniž by tyto skupiny měly a priori rozdílné dispozice). 
zkušeností, které děti získávají pobytem ve vrstevnické skupině (Datnow \& Hubbard, 2002). Nicméně se ukazuje, že ačkoliv byla koedukace zaváděna jako opatření pro odstranění nerovností mezi dívkami a chlapci, bez náležité aktuální reflexe tento cíl neplní. V anglosaské pedagogické psychologii a sociologii vzdělávání již tři dekády probíhají výzkumy, které dokládají, že samotná koedukace nezaručuje spravedlivé a rovné zacházení s dívkami a chlapci (Klein et al., 2007; Skelton, Francis, \& Smulyan, 2006; Datnow \& Hubbard, 2002). Koedukace sice má potenciál prohlubovat rovné př́ležitosti dívek a chlapců, ale zároveň prostřednictvím ní může naopak docházet ke zdůrazňování genderových rozdílů. ${ }^{3}$ Aktuální studie ukazují, že ve smíšených třídách roste inklinace $\mathrm{k}$ odlišným očekáváním vůči dívkám a chlapcům a k upozorňování na odlišnost jejich projevů, přičemž rozdíly mezi skupinami zastíní rozdíly mezi jednotlivými dětmi (Hayes, Pahlke, \& Bigler, 2011). To, v čem se od sebe liší jednotlivé dívky, respektive jednotliví chlapci, se dostane do pozadí, a naopak do popředí vystoupí „průměrné“ odlišnosti skupiny dívek od skupiny chlapců.

Dopady koedukace se nejvíce studují na komunikaci vyučujících mezi dívkami a chlapci (Datnow \& Hubbard, 2002). Většina výzkumů týkajících se školní docházky od 6 do 18 let se shoduje na tom, že chlapci v průměru komunikují s vyučujícími více než dívky, přičemž největší rozdíl existuje v období puberty (Jones \& Dindia, 2004). Četnější komunikace mezi vyučujícími a chlapci vyplývá z kombinace následujících tendencí: (1) vyučující kladou chlapcům více otázek než dívkám a otázky formulují otevřeněji a procesuálně; (2) chlapci více než dívky iniciují kontakt s vyučujícími, kteří navíc na jejich podněty častěji a déle reagují; (3) v důsledku obou předchozích bodů chlapci v hodinách hovoří více než dívky; (4) vyučující si více všímají a komentují chování a výkony chlapců než dívek; ${ }^{4}$ (5) ačkoliv určité porušo-

3 Pojem gender používám v tradici feministických teorií (Buttler, 1990; Kimmel, 2000 aj.) ve významu sociálně konstruované představy maskulinity a femininity. Prostřednictvím výchovného působení rodičů a vyučujících a systémového nastavení institucí, včetně rodiny a školy, se dívky a chlapci těmto představám přizpůsobují (Beal, 1993). Reagovat mohou také modifikací či odmítnutím genderových požadavků, což však bývá sociálně i identitně náročné. Vzhledem $\mathrm{k}$ tomu, že koncept genderu je v sociálních vědách již plně etablovaný, nepovažuji za nutné věnovat se jeho představování podrobněji.

4 Chlapcům je věnována větší pozornost ve všech věkových skupinách a bez ohledu na pohlaví vyučujících. Podle některých studií (Einarsson \& Granström, 2002) ovšem v případě učitelůmužů relativně narůstá pozornost věnovaná dívkám v období dospívání (nepřesahuje však pozornost věnovanou chlapcům), což však může být důsledkem větší snahy o interakce ze strany dívek. 
vání pravidel je u chlapců akceptováno více než u dívek (např. vykř̌ikování), jsou chlapci disciplinováni silněji než dívky (Jones \& Dindia, 2004; Einarsson \& Granström, 2002; Skelton et al., 2006; Klein et al., 2007). Je třeba zdůraznit, že uvedené body představují „pouze“ tendence. Neplatí, že by jim podléhali ve stejné míre všichni vyučující a ve všech třídních kolektivech, ani že by $\mathrm{v}$ jednotlivých skupinách bylo zcela stejně přistupováno ke všem dívkám a ke všem chlapcům. ${ }^{5} \mathrm{~V}$ konkrétních podmínkách výuky se gender vždy kombinuje s dalšími faktory, které prohlubují nebo oslabují platnost popsaných tendencí. Nejsilnější vliv mají vyučující a jejich představy o žácích a žákyních a dále genderové sociální normy platné v konkrétní třídě.

\section{Oddělené vzdělávání dívek a chlapců}

Z uvedených nálezů vyplývá, že koedukovaná výuka může vyvolávat značné nevýhody a vést $\mathrm{k}$ genderové nerovnosti ve výsledcích. Př́tomnost dívek a chlapců $\mathrm{v}$ jednom kolektivu svádí $\mathrm{k}$ tomu, aby se $\mathrm{k}$ dětem přistupovalo jako k členům/kám těchto dvou skupin, které se homogenizují, a odhlíželo se od jejich individuálních specifik. Psychologické a pedagogické výzkumy dokládají rizika koedukace již více než 30 let. V zahraničí spočívaly reakce na tyto nálezy v zavádění praktických opatření do škol, přičemž se nejčastěji jednalo o úpravy dvou typů - nahrazování koedukace segregovanou výukou a zvyšování informovanosti vyučujících o genderu. Druhé opatření týkající se vyučujících je namířeno jak na školy uplatňující oddělenou výuku chlapců a dívek, tak na školy koedukované. Ukazuje se totiž, že negativní důsledky koedukace nastávají zejména $\mathrm{v}$ těch případech, kdy vyučující nedisponují dobrým povědomím o existenci genderových stereotypů - pokud si neuvědomují jejich možný vliv, nedokáží se jim bránit a stereotypy se v jejich myšlení a chování zákonitě projeví. Zároveň ale i nereflektovaná genderová segregace může vést $\mathrm{k}$ uplatňování genderových stereotypů, protože vyučující mohou oddělené školy či třídy a priori spojovat s odlišností dívek a chlapců. Učitelské povědomí o genderových stereotypech a jejich reflexe v projevech dětí i svých vlastních je tedy podmínkou pro prohloubení pozitivních efektů obou forem vzdělávání.

Někteří autoři/ky hovoří o absenci genderových nerovností, protože se nevýhody obou skupin „vykrátí“. Toto pojetí však považuji problematické, jelikož celková rovnost není sumou jednotlivých dílčích znevýhodnění, nýbrž už jen existence těchto dílčích znevýhodnění může (zvláště při spojení s dalšími třídícími znaky) způsobit pro konkrétní jedince zabrzdění jejich vzdělávací trajektorie a nevyužití jejich kognitivního potenciálu. 
V zemích, které reflektovanou genderově oddělenou výuku zavedly či obnovily, jako je Austrálie, Nový Zéland, USA, Velká Británie, Německo, Nizozemí aj., existuje pluralita organizačních forem, které se liší stupněm segregace (Datnow \& Hubbard, 2002; Gibb, Fergusson, \& Horwood, 2008). Nejhlubší segregace je na úrovni škol, které jsou bud' určeny pro chlapce, nebo pro dívky. ${ }^{6}$ Mírnější oddělení je na úrovni tříd, kdy jednotlivé kolektivy navštěvují bud' jen dívky, nebo chlapci, ale škola zahrnuje oba typy tříd, a proto se obě skupiny mohou pravidelně setkávat mimo výuku i při školních akcích. Ještě mírnější je segregace předmětová, při níž děti dochází do koedukované třídy, ale na některé předměty (nejčastěji na matematiku a přírodovědné předměty) probíhá výuka odděleně. Nejméně striktní je segregace občasná, kdy výuka všech předmětů standardně probíhá ve smíšených třídách, ale výjimečně jsou děti rozděleny na dvě genderově homogenní skupiny a následně reflektují, zda a v čem se vyučovací hodina lišila. Na základě toho si lépe uvědomí výhody a rizika koedukace a získanou zkušeností zpětně ovlivní klima ve smíšené třídě. Každý vzdělávací systém upřednostňuje vzhledem ke své tradici určitý model genderové segregace, takže nelze na základě výzkumů stanovit, který z nich je nejlepší. Přesto se praxe kloní spíše k vnitřní diferenciaci škol, tj. k odděleným předmětům či eventuálně třídám, které v sobě kombinují výhodu obou organizačních forem (Jackson, 2002; Datnow \& Hubbard, 2002). U všech typů segregací platí, že mají-li vést k rovným výsledkům dívek a chlapců, musí být realizovány záměrně a explicitně, s reflexí genderových stereotypů. Z tohoto hlediska pak český zvyk oddělené výuky tělesné výchovy či pracovních činností není případem diferenciace směřující k genderové rovnosti, nýbrž naopak se může jednat a často se jedná o model zdůrazňující údajnou odlišnost dívek a chlapců. ${ }^{7}$

6 Důležitou výhradou vůči genderové segregaci je „nepřirozenost“. Je-li škola vnímána jako příprava na vstup do společnosti, v níž se muži a ženy permanentně setkávají, pak je po ní žádáno, aby simulovala obdobné podmínky. Tato kritika je však platná pouze v př́padě segregace na úrovni škol, protože v nižších typech segregace (třídy, předměty, hodiny) jsou chlapci a dívky v každodenních kontaktech.

7 V uvedených dvou předmětech bývá oddělená výuka považována za přijatelnou, ba samozřejmou do té míry, že ji není nutné v kontextu koedukovaného školství specificky zdủvodňovat. Historicky se důvody nacházely v rozdílech ve fyzické síle chlapců a dívek, v tělesné senzitivitě dospívajících, v odlišných dispozicích a zájmech o určité činnosti a v potřebnosti osvojit si typicky mužské a ženské dovednosti (tj. technická zručnost versus vaření). Společným jmenovatelem těchto důvodů jsou genderové stereotypy, které vytváří bazální představu o přirozené a nezměnitelné odlišnosti žen a mužů (Beal, 1993). U většiny z uvedených argumentů platí, že pokud by byly založené biologicky (tj. bez vazby na sociálně konstruovanou femininitu a maskulinitu), pak by se pro vytvoření výukových skupin musely využívat jiné postupy, např. vstupní fyzické testy či dotazy na zájmy konkrétních dětí, jejichž prostřednictvím by se pravděpodobně stalo zastoupení chlapců a dívek vyrovnanější. 


\section{3 Školní výsledky a sociální vztahy ve smíšených a oddělených třídách}

Vyjdeme-li z dostupných výzkumů srovnávajících koedukovanou a oddělenou výuku na úrovni základních a středních škol, nacházíme důkazy o rozdílech ve třech oblastech: (1) v chování a zapojení dívek a chlapců do výuky, (2) v postojích chlapců a dívek k učení, (3) ve školních výsledcích. Ve všech třech oblastech přitom existuje převaha důkazů o neutralitě až výhodnosti oddělené výuky, přičemž některé faktory, jako je věk a pohlaví/gender dětí, vyučovací předmět a přístup vyučujících, výhodnost zesilují (Jones \& Dindia, 2004; Jackson, 2002; Gibb et al., 2008). Následující odstavce ve stručnosti nastíní, jaké jsou hlavní závěry zahraničních výzkumů v uvedených třech oblastech.

Co se týče žákovského zapojení do výuky, výzkumy ukazují, že studentky v oddělených třídách jsou aktivnější a častěji produkují chování, které v sobě obsahuje určité riziko, např. iniciování otázek směrem k vyučujícím nebo vykř̌ikování odpovědí (Hayes et al., 2011). Zvláště patrné jsou tyto rozdíly $\mathrm{v}$ matematice a prŕrodovědných předmětech u dívek $\mathrm{v}$ pubertě (Hayes et al., 2011; Gibb et al., 2008). Na rozdíl od smíšených tříd, kde takové chování produkuje jen velmi malý počet žákyň, v ryze dívčích skupinách je výrazně četnější. Na straně chlapců jsou rozdíly v chování menší; týkají se zejména nižší míry vzájemného soupeření, které se projevuje vytahováním a agresí (Beal, 1993), což podporuje kooperaci ve výuce a usnadňuje vyučujícím zvládání kolektivu (Einarsson \& Granström, 2002; Streittmater, 2002). Omezené kontakty mezi dívkami a chlapci také oddalují „erotizaci“ sebeprezentace a vztahů (Skelton et al., 2006).

Studie žákovských postojů a pocitů naznačují, že v segregované výuce dívky zažívají větší sebejistotu při participaci na učebních aktivitách (Jeter \& Davis, 1982; Hayes et al., 2011). Důsledkem je, že vztah dívek ke školním předmětům, zvláště k př́rodovědným předmětům a matematice, se zlepšuje. $\mathrm{V}$ oddělené výuce dívky $\mathrm{v}$ technické a přírodovědné doméně celkově vykazují větší pocity kompetentnosti a akademických aspirací (Gibb et al., 2008). Naopak chlapecké postoje vůči jednotlivým vyučovacím předmětům nevykazují žádnou silnou souvislost se segregací výuky (Klein, 2007; Rudman \& Glick, 2010).

Oblast vzdělávacích výsledků bezprostředně vyplývá z dvou předcházejících oblastí. Pokud se děti ve škole cítí dobře a více se zapojují do výuky, pak je 
větší pravděpodobnost, že jejich školní výsledky zaznamenají zlepšení. Studie ukazují, že dívky v segregované výuce mají v porovnání s koedukací lepší výkony, a to zvláště $\mathrm{v}$ technických a př́rodovědných předmětech ${ }^{8}$ (Gibb et al., 2008; Einarsson \& Granström, 2002). To následně vede k nárůstu podílu dívek, které se hlásí ke studiu v těchto oborech. Naopak chlapecké výsledky a vzdělávací trajektorie žádné výrazné změny nevykazují, respektive jen velmi slabé (Jackson, 2002; Streitmatter, 2002).

Jak bylo naznačeno, část rozdílů mezi segregací a koedukací se dotýká i tř́́dního klimatu, tj. vzájemných vztahů v kolektivu a pocitů, které děti mezi ostatními zažívají. Studie však v tomto směru docházejí k nesourodým závěrům. Podle některých výzkumů segregace přispívá $\mathrm{k}$ hlubší přináležitosti a spolupráci mezi dětmi $\mathrm{v}$ homogenní skupině, podle jiných není v kvalitě klimatu segregovaných a smíšených tříd rozdíl (Hayes et al., 2011; Streitmatter, 2002). Zdá se, že třídní klima je více než na složení kolektivu závislé na sociálních normách, které se v něm vytvoří, a jejichž součástí jsou i genderové představy a požadavky (Klein et al., 2007). Ve skupinách se ustavuje různě silná genderová polarizace, která spočívá v oddělování dívek a chlapců a která homogenizuje maskulinitu a femininitu, tj. vytváří dominanci jedné úzké představy toho, co znamená být „správná holka“ a „správný kluk“ (Rudman \& Glick, 2010). Platí přitom, že slabší a flexibilnější genderové normy přispívají k pozitivnímu sociálnímu klimatu a snižují riziko šikany dětí, jejichž vzhled či chování neodpovídá obecně rozšířeným genderovým rolím (Skelton et al., 2006). Na základě výše uvedených poznatků lze předpokládat, že genderově oddělená výuka vyvolá při správném učitelském vedení zeslabování genderových norem, a tedy i zlepšování vztahů a jejich prostřednictvím školní spokojenosti a výkonnosti. Naopak nereflektovaná koedukace využívá a dále posiluje genderové stereotypy, které sociální normy, a tedy i celkové klima spíše zhoršují. Kromě učitelského přístupu závisí pozitivní efekty genderově oddělené výuky také na postoji samotných žáků a žákyň, nebot' pokud ji odmítají, je její zavedení a udržení problematické (Hayes et al., 2011; Streitmatter, 2002).

\section{Výzkumné šetření: cíl a metodologie}

Protože na českých školách existuje tradice koedukovaných tříd kombinovaných s oddělenou výukou určitých předmětů, disponují žáci a žákyně zku-

Segregace má také pozitivní vliv na výsledky marginalizovaných skupin chlapců (Datnow \& Hubbard, 2002). 
šenostmi s oběma typy výuky, které mohou porovnávat. Údaje o tom, jaké jsou žákovské postoje vůči koedukované a segregované výuce, ovšem nejsou k dispozici. Pro př́ípad, že by školy uvažovaly o rozšíření oddělené výuky, by znalost žákovských preferencí byla užitečná, nebot' na jejím základě lze navrhovat funkční opatření z hlediska výsledné organizační konstelace a způsobu jejího prosazování.

Cílem výzkumného šetření proto bylo zjistit, jak děti vnímají smíšené třrídní kolektivy a jak hodnotí své zkušenosti s výukou v oddělených dívčích či chlapeckých skupinách na druhém stupni základních škol a nižších stupních víceletých gymnázií. Šetření se realizovalo prostřednictvím dotazníku, který obsahoval deset baterií otázek. Sestavení dotazníku předcházela kvalitativní studie využívající 50 žákovských volných textů, které vznikly na základě zadání „kluci a holky ve společné třídě“. Jejich rozbor ukázal, že děti s koedukací spojují třri témata: (a) podobnost/rozdílnost vztahů v dívčích, chlapeckých a smíšených skupinách; (b) spravedlivý přístup vyučujících; (c) očekávání vůči chlapcům a dívkám. ${ }^{9}$ Ke každému z těchto témat byla formulována jedna, respektive dvě baterie otázek, které byly dále doplněny položkami týkajícími se míry zkušeností s oddělenou výukou, preferovaného složení tříd a identifikačních údajů. ${ }^{10}$ Většina položek představovala hodnocení výroků na škále dle souhlasu nebo hodnocení skupinových charakteristik na škále dle jejich přináležitosti k dívčímu či chlapeckému kolektivu, a to vždy s možností středové, neutrální odpovědi. ${ }^{11}$ Dotazník prošel pilotáží na 20 respondentech/kách.

Dotazníkové šetření proběhlo ve 29 třídách na druhém stupni základních škol a 8 třídách víceletých gymnázií z celé České republiky. 0 spolupráci byli požádáni konkrétní vyučující, kteří se zúčastnili semináře k vedení tř́́dních kolektivů. Ze 71 zúčastněných osob bylo osloveno 42, a to ze škol, které lze v daném typu označit za běžné, přičemž rozhodující byla velikost školy

9 Postoje a hodnocení žákovských zkušeností s koedukovanou výukou představuje téma vhodné pro kvalitativní metodologii. Výsledky kvalitativní analýzy žákovských textů, která představovala 1. fázi výzkumu, budou představeny v samostatném článku. Protože mezi dětskými popisy panovala vysoká konzistence, bylo přistoupeno $\mathrm{k}$ rozšsiřřní výzkumu o kvantitativní dotazníkové šetření, které je prezentováno v tomto textu.

${ }^{10} \mathrm{~V}$ tomto článku jsou představeny výsledky z baterií týkajících se hodnocení smíšené a oddělené výuky. Baterie vztahující se k přístupu vyučujících jsou předmětem jiného textu.

$11 \mathrm{~V}$ př́padě hodnocení skupinových charakteristik bylo $\mathrm{v}$ zadání explicitně uvedeno, že charakteristika nemusí mít vztah ke složení skupiny. Položky tedy nesugerovaly nutnost uvažovat o skupinách prizmatem genderu/pohlaví, což je klíčové pro následnou interpretaci výsledků. 
( 2 paralelní třídy ve většině ročníků), absence deklarované alternativnosti školního vzdělávacího programu a lokalita. ${ }^{12}$ Vyučující provedli zadání dotazníkủ ve svých hodinách podle podrobných instrukcí a následně dotazníky odeslali. Všechna data z dotazníků byla převedena do elektronické podoby a dále podrobena statistickým procedurám. Kromě třídění prvního a druhého stupně byla použita faktorová analýza a testy shody průměrů.

Celkem byly vyplněné dotazníky shromážděny od 578 dětí, avšak 22 dotazníků bylo kvůli chybějícím údajům vyřazeno ze zpracování. Analyzovaný soubor tvořila data od 556 studujících, z nichž $52 \%$ byly dívky a $48 \%$ chlapci. Všechny třídy byly smíšené, a to nejméně v poměru $40 \%$ dívek či chlapců. $\mathrm{Z}$ hlediska typu školy bylo 80 \% dětí ze základních škol a $20 \%$ z víceletých gymnázií. Šetření záměrně mířilo na vyšší ročníky, protože u starších dětí lze předpokládat více zkušeností s oddělenou výukou a zároveň větší schopnost obě formy porovnávat. Podíl dětí od šestých do devátých ročníků činil 8,3 \%, $11,7 \%, 34,7 \%$ a $45,3 \%$.

Původní předpoklad se potvrdil - děti z vyšších ročníků referovaly o četnějších zkušenostech s oddělenou výukou. Celkem více než 3/4 studujících uváděly, že v jejich třídě se běžně využívá výuka v separovaných skupinách. Podle dívek dochází k oddělené výuce častěji než podle chlapců - rozdíl činí osm procentních bodů, což není statisticky signifikantní $(\alpha=0,05)$. Nicméně, tento i předcházející údaj svědčí o nepřesnostech v žákovském vnímání, na které musíme brát zřetel při interpretaci všech výsledkủ. Výzkum nicméně nesměřoval $\mathrm{k}$ deskripci podmínek výuky, nýbrž $\mathrm{k}$ postojům žáků a žákyň, které se mohou demonstrovat právě i v rozdílném vnímání okolností výuky, respektive $\mathrm{v}$ jejich odlišném zvýznamňování. Jak vyplynulo z konfrontace s vyučujícími, kteří dotazníky zadávali, na všech školách je oddělená výuka používána, a proto s ní všichni respondenti/ky mají zkušenosti, o nichž však nereferovali. Protože $v$ jiných aspektech byly dotazníky vyplněny řádně, lze usuzovat, že oddělená výuka je pro děti natolik samozřejmý a přirozený fenomén, že jej nevnímají jako specifický a v otázce na „oddělené vyučování dívek a chlapců“ ji opomenou uvést.

Cílem bylo, aby soubor obsahoval zastoupení škol z velkých měst, menších měst a vesnic. Z výsledných 37 škol bylo 5 škol vesnických, 7 škol z obcí do 5000, 8 škol z měst do 25000 , $10 \mathrm{z}$ velkých měst a $7 \mathrm{z}$ Prahy. Velikost obce či typ školy (gymnázium/ZŠ) nejsou v této analýze zohledňovány. 


\section{Dívčí a chlapecký kolektiv}

Na základě rozboru volných žákovských textů bylo vygenerováno 13 charakteristik, které děti uváděly ve spojitosti se zastoupením dívek a chlapců v kolektivu, a to jako typický rys homogenního kolektivu. Dotazník pak měl ověřit, jaký je podíl žáků/kyň, kteří vnímají uvedené charakteristiky jako genderově specifické, tj. vyskytující se spíše v dívčích nebo spíše v chlapeckých skupinách, př́padně ve stejné míře v obou. Posuzované atributy a podíl odpovědí přiřazujících je k jednotlivým typům skupin ukazuje tabulka 1.

Tabulka 1

Přirazení charakteristik ke skupinám (v \%), $N=556$

\begin{tabular}{lrrr}
\hline Charakteristika & $\begin{array}{c}\text { Dívčí } \\
\text { skupiny }\end{array}$ & $\begin{array}{l}\text { Chlapecké } \\
\text { skupiny }\end{array}$ & Obě skupiny, neutrální \\
\hline 1. Legrace, zábava & 2,0 & 11,3 & 85,2 \\
2. Pomlouvání & 57,5 & 3,9 & 32,2 \\
3. Fyzické násilí, praní & 2,2 & 83,5 & 7,7 \\
4. Dobrá spolupráce & 18,3 & 6,6 & 68,3 \\
5. Důvěrné informace o druhých & 46,7 & 5,0 & 33,1 \\
6. Vytahování & 7,0 & 48,1 & 33,3 \\
7. Hádky a neshody & 27,3 & 8,5 & 58,7 \\
8. Vzájemná pomoc a podpora & 19,5 & 4,5 & 67,8 \\
9. Dobrá organizace úkolů & 38,2 & 7,3 & 41,6 \\
10. Soutěživost & 7,6 & 35,8 & 50,0 \\
11. Pohoda & 8,5 & 19,9 & 66,0 \\
12. Rovnost mezi všemi & 11,8 & 7,9 & 51,3 \\
13. Vytváření malých skupinek & 28,5 & 6,5 & 51,3 \\
\hline
\end{tabular}

Pozn.: Řádkový součet 100 \% zahrnuje i odpověd' nevím a chybějící odpovědi, kterých bylo maximálně 3,5 \%.

Na základě odpovědí lze mezi charakteristiky společné homogenním dívčím i chlapeckým skupinám zařadit následující: legrace a zábava, dobrá spolupráce, vzájemná pomoc a podpora, pohoda, ale také hádky a neshody. Všechny další atributy byly označovány za společné pro obě skupiny méně než polovinou dětí. Ve zvolených charakteristikách můžeme vysledovat dva společné jmenovatele. Jedním je kladná emoční valence - až na hádky odkazují všechny atributy k pozitivnímu sociálnímu klimatu. Druhým je vztahovost - až na spolupráci, která je více spojena s výkony, se všechny atributy týkají afek- 
tivní dimenze interpersonálních vztahů. S homogenními kolektivy jsou však spojovány rovněž vztahové charakteristiky, které však mají záporný náboj. Chlapecké kolektivy děti asociují s fyzickým násilím a praním, dívčí kolektivy s pomlouváním. ${ }^{13}$ Při interpretaci těchto údajů je nutné mít na paměti, že společné charakteristiky nevypovídají o smíšených kolektivech, nýbrž o atributech vyskytujících se podle dětí jak v dívčích, tak chlapeckých skupinách. Lze tedy předpokládat, že se jedná o atributy genderově neutrální, na které složení skupiny nemá vliv.

Vedle frekvence jednotlivých atributů je podstatné také jejich vzájemné uspořádání, které bylo zjištóváno faktorovou analýzou (tabulka 2). Z ní vyplynula existence tří silných faktorů, které lze pojmenovat jako (1) konflikty, (2) uvolněnost, (3) pracovní klima. Jedná se o dimenze, v nichž děti posuzují kvalitu skupiny, zvláště při zdůraznění podílu dívek a chlapců. Významné je, že oddělují výkonovou a afektivní stránku vztahů ve skupinách, přičemž při posuzování afektivity uvažují zvlášt' negativní a pozitivní aspekty.

Tabulka

\section{Charakteristiky skupin, faktorová analýza (rotovaná matice)}

\begin{tabular}{llcr}
\hline Charakteristika & Faktor 1 & Faktor 2 & Faktor 3 \\
\hline 1. Legrace, zábava & 0,213 & 0,059 & 0,710 \\
2. Pomlouvání & 0,665 & 0,111 & 0,167 \\
3. Fyzické násilí, praní & 0,406 & 0,480 & $-0,253$ \\
4. Dobrá spolupráce & $-0,103$ & 0,563 & 0,474 \\
5. Důvěrné informace o druhých & 0,244 & 0,644 & $-0,068$ \\
6. Vytahování & 0,549 & 0,224 & 0,199 \\
7. Hádky a neshody & 0,714 & 0,127 & 0,216 \\
8. Vzájemná pomoc a podpora & $-0,005$ & 0,563 & 0,317 \\
9. Dobrá organizace úkolů & 0,048 & 0,551 & 0,137 \\
10. Soutěživost & 0,238 & 0,094 & 0,475 \\
11. Pohoda & 0,167 & 0,118 & 0,640 \\
12. Rovnost mezi všemi & 0,015 & 0,116 & 0,056 \\
13. Vytváření malých skupinek & 0,508 & 0,103 & $-0,072$ \\
\hline
\end{tabular}

Pozn.: Extraction Method: Principal Component Analysis. Rotation Method: Varimax with Kaiser Normalization. Položky sytící jednotlivé faktory jsou označeny šedě.

13 Charakteristiky spojené s preferovaným typem agrese (verbální versus fyzická) jsou jednoznačně genderově sycené. To se týká částečně také míry agrese, nebot’ spojení tělesného násilí s chlapeckými skupinami je výrazně silnější než spojení pomlouvání s dívčími skupinami (rozdíl je 26 procentních bodů). 
Na základě konkrétní náplně faktorů lze předpokládat, že negativní aspekty (konflikty) představují především individuální útoky, které se projevují na úrovni konkrétních interpersonálních vztahů, zatímco pozitivní aspekty (uvolněnost) jsou spíše celkovou charakteristickou skupiny. Z toho vyplývá, že oba aspekty se mohou vyskytovat zároveň - i ve skupině, kde panuje pohoda a legrace, může mezi konkrétními osobami nastat spor. Při posuzování konfliktnosti coby skupinového znaku však musí být překročena tato individuální úroveň, respektive musí být výrazně zmnožena.

Jak je patrné z tabulky 2 , některé položky sytí více faktorů. Konkrétně se jedná o položku fyzické násilí, praní, která se vztahuje jak ke konfliktům, tak $\mathrm{k}$ uvolněnosti. Fyzické potyčky jsou jedním z projevů nevraživosti mezi dětmi. Zároveň platí, že se vyskytují zejména mimo vyučovací hodiny, tj. v čase a místě bez dohledu dospělé autority, kdy děti pocit’ují určitou autonomii a volnost. Část dětí navíc v potyčkách nevidí pouze vrstevnickou averzi, ale spíše kamarádské pošt'uchování. Druhou položkou, která se vztahuje jak k uvolněnosti, tak k pracovnímu klimatu, je dobrá spolupráce a částečně také vzájemná podpora a pomoc. Tyto charakteristiky jsou př́tomny ve vrstevnických aktivitách (např při hrách), ale také při převedení do kontextu výuky podporují úspěšné plnění školních úkolů.

Dosud byla pozornost věnována celkovým výsledkům, které se však mírně liší, porovnáváme-li odpovědi dívek a chlapců. Základní trend chlapeckých a dívčích odpovědí je shodný - jak dívky, tak chlapci nejsilněji spojují dívčí kolektivy s pomlouváním a chlapecké s fyzickým násilím. Ovšem míra přiřazení těchto i dalších charakteristik k typu kolektivu kolísá. Následující tabulka 3 zachycuje charakteristiky, v nichž se odpovědi dívek a chlapců statisticky významně liší $(\alpha=0,05)$.

Tabulka 3

Charakteristiky homogenních kolektivů, největší rozdíly v odpovědích dívek a chlapců ( $v \%), N=556$

\begin{tabular}{lll}
\hline & Odpovědi dívek & Odpovědi chlapců \\
\hline Dívčí & pomlouvání $(62,3: 52,1)$ & - \\
kolektiv & důvěrné informace o druhých $(55,6: 37,1)$ & \\
& vytváření malých skupinek $(34,3: 22,3)$ & \\
Chlapecký & vytahování $(53,4: 42,2)$ & legrace, zábava $(5,0: 18,1)$ \\
kolektiv & & dobrá spolupráce $(2,9: 10,6)$ \\
& & pohoda $(11,3: 29,1)$ \\
& & pomoc a podpora $(1,1: 8,1)$ \\
& soutěživost $(31,2: 40,8)$ \\
\hline
\end{tabular}

Pozn.: Údaje v závorkách představují odpovědi dívek a odpovědi chlapců v \%. 
Jak je z výčtu charakteristik patrné, chlapci posuzují vlastní skupiny pozitivněji v porovnání s tím, jak chlapecké kolektivy vidí dívky. Zatímco dívky více než chlapci asociují s chlapeckými skupinami vytahování, které je jednoznačně zápornou charakteristikou, sami chlapci vyzdvihují (oproti dívkám) výhradně pozitivní atributy. Jedinou výjimkou může být soutěživost, která má ambivalentní valenci. ${ }^{14}$ Naopak děvčata více než chlapci považují za typické rysy dívčích skupin negativně hodnocené pomlouvání a vytváření skupinek a pouze jednu pozitivní či ambivalentní charakteristiku, kterou je množství důvěrných informací (ambivalentnost vyplývá z toho, že informace o druhých jsou podmínkou pro pomlouvání). Chlapecký pohled na dívčí kolektiv neobsahuje žádný specifický atribut.

Z těchto nálezů vyplývají dva závěry: (1) obraz o vlastní skupině je obsáhlejší a vyhrocenější než obraz o skupině cizí, (2) obraz dívek o vlastní skupině je kritičtější než sebeobraz chlapců. Oba závěry jsou v souladu se stávajícím poznáním. Na poli meziskupinové percepce byly popsány principy utváření dojmu o vlastních a cizích skupinách (Hnilica, 2010). Představa o členské skupině bývá komplexnější a méně generalizovaná, protože jedinec má k dispozici velké množství detailních informací. Zároveň bývá představa o členské skupině kvůli potřebě silné osobní identity pozitivní, nebot' negativní obraz skupiny snižuje přináležitost k ní. Oblastí, k níž se vztahuje druhé zjištění, je genderový řád společnosti a jeho vliv na skupinové a interpersonální vztahy (Rudman \& Glick, 2010). Jedním z pilírư genderového řádu je androcentrismus, tj. nadřazenost maskulinity nad femininitou. Jak dokládají četné psychologické studie (např. Gilligan, 2001), většina dívek, zvláště v dospívání, kdy se formuje osobní identita, má vůči ženskosti, ostatním dívkám/ženám a dívčím skupinám ambivalentní až kritický postoj, a to v míře, která vysoce překračuje kritičnost chlapců vůči maskulinitě.

\section{Vztahy ve smíšené skupině}

Jak bylo uvedeno, všechny třídy účastnící se výzkumu byly smíšené, ale probíhala v nich oddělená výuka minimálně v jednom vyučovacím předmětu. Dotazník obsahoval tři položky, které se týkaly toho, jak děti hodnotí své zkušenosti s koedukací a segregací a který z těchto modelů by eventuálně preferovaly.

14 Hodnocení charakteristik vysuzuji jednak z žákovských komentářů v rámci polouzavřených položek v dotazníku a jednak z rozboru polostrukturovaného psaní, které předcházelo formulaci dotazníku. 
Zahraniční studie dokládají, že $\mathrm{v}$ adolescentních smíšených kolektivech často dochází k neshodám až obtěžování s genderovým rozměrem (Beal, 1993; Skelton et al., 2006). Proto byla v dotazníku položena otázka, zda ve tř́́dách existují spory a obtěžování mezi dívkami a chlapci. Takové projevy potvrdilo $71 \%$ studujících. Dívčí a chlapecký pohled se statisticky významně lišil $(\alpha=0,05)$. Chlapci referovali o těchto zkušenostech více než dívky (66 \% ku 76 \%). Nižší frekvence zkušeností u dívek může být způsobena bud' tím, že se dívky skutečně setkávají s genderově motivovanými konflikty a obtěžováním méně než chlapci, nebo tím, že jsou dívky k problematickému chování shovívavější, tj. neoznačují takové chování za obtěžování (spory mezi dívkami a chlapci považují za normu), a tudíž ho přehlíží. ${ }^{15}$

V další položce děti porovnávaly své pocity při práci ve smíšených a oddělených skupinách. Zhruba $2 / 3$ z nich mezi oběma konstelacemi nevidí zásadní rozdíl, ovšem podle $12 \%$ dětí je práce v pouze dívčí či chlapecké skupině horší, zatímco podle 23 \% naopak lepší. Při pozitivním hodnocení děti vyzdvihují jako hlavní důvody lepší vzájemnou domluvu a větší legraci, tedy charakteristiky, které podle nich jsou genderově neutrální. Pohled dívek a chlapců je téměř shodný - dívky sice mírně častěji hodnotí obě uspořádání jako srovnatelná, ale rozdíl není statisticky signifikantní $(\alpha=0,1)$.

Studující byli dále dotázáni, jaké zastoupení chlapců a dívek ve třídě by osobně preferovali. Výsledky ukazuje tabulka 4 . Téměř $2 / 3$ dětí dávají přednost rovnoměrnému zastoupení, zatímco jen $2 \%$ by si přály genderově homogenní kolektivy. Je evidentní, že děti odmítají genderovou segregaci, což platí silněji u dívek než chlapců $\left(\chi^{2}=0,0081\right)$. Zároveň si ale také nepřejí třídy s převahou vlastní skupiny. Pokud připouští nerovnoměrné složení, pak preferují převahu opačné skupiny. $V$ otevřené otázce to dívky zdůvodňovaly tím, že v kolektivu s více chlapci neprobíhá tolik pomlouvání, zatímco chlapci uplatňovali sexuální zájem („bylo by se na co koukat“, „lepší úspěch v balení“ aj.). Opět zde tedy vstupuje do hry větší kritičnost dívek vůči femininitě a zároveň apriorní sexualizaci vztahů mezi dívkami a chlapci.

15 Obdobné výsledky vyplynuly z výzkumu genderově motivovaného obtěžování v žákovských kolektivech středních škol (Smetáčková \& Pavlík, 2012). 
Tabulka 4

Preference složení skupin (v \%), $N=556$

\begin{tabular}{lccc}
\hline Složení třídy & Celkem & Dívky & Chlapci \\
\hline Polovina dívek a polovina chlapců & 62,3 & 73,4 & 50,2 \\
Pouze dívky nebo pouze chlapci & 2,2 & 1,0 & 3,4 \\
Více dívek, méně chlapců & 20,8 & 6,6 & 36,1 \\
Více chlapců, méně dívek & 14,8 & 18,9 & 10,3 \\
\hline
\end{tabular}

Preference rovnoměrně smíšených tříd variuje v závislosti na věku. Postoj dívek kolísá - slabší podpora shodnému zastoupení panuje mezi dívkami ve věku 12 a 14 let, silnější ve 13 a 15 letech. Chlapecký postoj se lineárně vyvíjí od nižší k silnější preferenci (35\% ku 52 \%) a spolu s tím postupně narůstá zájem o kolektiv s převahou dívek. Podíl dětí, které by chtěly pobývat ve vlastní homogenní skupině (tj. pouze dívky či pouze chlapci), je nejvyšší mezi nejmladšími respondenti/kami. Až 15 \% dvanáctiletých dívek a 18 \% chlapců preferuje segregovanou tř́idu. U starších dívek se toto přání nevyskytuje vůbec, u starších chlapců se sice zájem o ryze chlapecké kolektivy zcela neztrácí, ale výrazně ubývá (z 18 \% k 1 \%).

Tyto výsledky jsou na první pohled v rozporu se zahraničními výzkumy žákovských preferencí, $\mathrm{v}$ nichž se ukazuje, že $\mathrm{v}$ oddělených třídách děti a zvláště dívky zažívají lepší sociální klima (Hayes et al., 2011). Mají-li děti srovnání mezi oddělenou a koedukovanou výukou, pak podstatná část dívek dává přednost segregaci, ovšem mezi chlapci je tento podíl nižší (Streitmatter, 2002). Dívky zejména oceňují větší prostor pro učení a lepší pracovní výsledky, protože se cítí méně rušené a omezované přítomností chlapců. ${ }^{16}$ Tento závěr lze však zároveň zpochybnit jinými studiemi, které naznačují, že děti z koedukovaných tříd preferují právě toto uspořádání a odmítají segregaci (Jackson, 2002; Jones \& Dindia, 2004; Einarsson \& Granström, 2002). České výsledky by pak odpovídaly takové interpretaci, že žáci a žákyně obhajují ten model výuky, na který jsou zvyklí a který se musí (z identitních důvodů) naučit oceňovat.

16 Rovněž část chlapců ve výzkumech uvádí, že v oddělené výuce „více pracují, protože je nerozptyluje atraktivita dívek (Streitmatter, 2002). 


\section{Závěr}

Z dotazníkového šetření vyplynulo, že žáci a žákyně ve věku 12 až 15 let mají navzdory kmenovým smíšeným tř́ídám řadu zkušeností s oddělenou výukou, které však obsahují určité vnitřní rozpory. Ačkoliv děti spojují s koedukací řadu negativních zážitků, celkově ji vítají. Tento nález je v souladu $\mathrm{s}$ těmi zahraničními výsledky, které říkají, že děti chtějí setrvat v modelu výuky, jenž znají, ačkoliv vůči němu mohou mít výhrady. Záporné pocity spojené s koedukací, o nichž děti v dotazníku vypovídaly, se týkají vrstevnických vztahů. Podle zkušeností podstatné části dětí generuje smíšený kolektiv genderově motivované spory a obtěžování. Ty vyrůstají jednak z genderových stereotypů, kterými se konkrétní dívky a chlapci cítí omezováni, jednak ze sexualizace vztahů mezi dívkami a chlapci (spíše než neutrální kamarádství děti za přirozený typ vztahu mezi dívkou a chlapcem považují partnerství). Navzdory těmto záporným aspektům děti spíše odmítají existenci homogenních tříd, což znamená, že tomuto negativnímu hodnocení nepřikládají velký význam, zřejmě proto, že pokládají koedukaci za samozřejmou a nezpochybnitelnou.

Na druhé straně děti nepovažují klima a aktivity ve smíšených a oddělených skupinách za př́liš odlišné. S výjimkou agrese je pobyt v obou skupinách spojen s pozitivními vztahovými charakteristikami a rovněž způsob školní práce dětem vyhovuje a je podle nich obdobný. Toto zjištění neodpovídá zahraničním nálezům, které alespoň u dívek potvrzují vnímání značných rozdílů mezi oběma typy výuky a preferenci segregace. Je však třeba připomenout, že zahraniční výzkumy mapují segregaci reflektovanou a záměrnou, v níž i děti jsou vedeny $\mathrm{k}$ uvědomování si genderového řádu, zatímco naopak do českého šetření vstoupily děti ze škol, kde probíhá oddělená výuka „naslepo“, a proto pravděpodobně podléhá genderovým stereotypům.

Paradoxně můžeme na základě českých zjištění usuzovat, že pokud je pobyt v homogenních skupinách pro dívky i chlapce spojen s pozitivními charakteristikami (až na agresi), nemuselo by zavedení segregace mít negativní důsledky pro třídní klima. Jednalo by se tedy de facto o argument pro oddělenou výuku, pokud by její zavedení/rozšíření bylo vedeno snahou o eliminaci genderových nerovností. Aby bylo zároveň zohledněno přání dětí pobývat $\mathrm{v}$ koedukované tř́dě, byla by nejvhodnější vnitřní diferenciace na úrovni některých vyučovacích předmětů nebo vyučovacích hodin. 


\section{Literatura}

Beal, C. R. (1993). Boys and girls: The development of gender roles. New York: McGraw-Hill Humanities.

Buttler, J. (1990). Gender trouble. Feminism and the subversion of identity. New York: Routledge.

Coleman, J. S. (1993). Equality and achievement in education (social inequality). London: Westview Pr.

Datnow, A., \& Hubbard, L. (Eds.). (2002). Gender in policy and practice. Perspectives on single-sex and coeducational schooling. New York: Routledge.

Einarsson, Ch., \& Granström, K. (2002). Gender-biased interaction in the classroom: The influence of gender and age in the relationship between teacher and pupil. Scandinavian Journal of Education Research, 46(2), 117-127.

Gilligan,C. (2001). Jiným hlasem. Praha: Portál.

Gibb, S. J., Fergusson, D. M., \& Horwood, L. J. (2008). Gender differences in educational achievement to age 25. Australian Journal of Education, 52(1), 63-80.

Hnilica, K. (2010). Stereotypy, předsudky, diskriminace (pojmy, měření, teorie). Praha: Karolinum.

Hayes, A. R., Pahlke, E. E., \& Bigler, R. S. (2011). The efficacy of single-sex education: Testing for selection and peer quality effects. Sex Roles, 65(9), 693-703.

Jackson, C. (2002). Can single-sex classes in co-educational schools enhance the learning experiences of girls and/or boys? An exploration of pupils' perceptions. British Educational Research Journal, 28(1), 37-48.

Jeter, J. T., \& Davis, O. L. (1982). Differential classroom interaction in social studies as a function of differential expectations of pupil achievements. Journal of Social Studies Research, 6(winter), 1-7.

Jones, S. M., \& Dindia, K. (2004). A meta-analytic perspective on sex equity in the classroom. Review of Educational Research, 74(4), 443-471.

Kimmel, M. (2000). The gendered society. New York: Oxford University Press.

Klein, S. S., Richardson, B., Grayson, D. A., Fox, L. H., Kramarae, Ch., Pollard, D. S., \& Dwyer, C. A. (2007). Handbook for achieving gender equity through education. New York: Routledge.

Rudman, L. A., \& Glick, P. (2010). The social psychology of gender. New York: Guilford Press.

Skelton, Ch., Francis, B., \& Smulyan, L. (2006). The SAGE handbook of gender and education. London: Sage Publication.

Smetáčková, I., \& Pavlík, P. (2012). Genderově motivované a sexuální obtěžování na středních školách: Hranice vhodného chování. Sociální studia, 10(3), 11-30.

Streitmatter, J. (2002). Perceptions of a single-sex class experience: Females and males see it differently. In A. Datnow \& L. Hubbard (Eds.), Gender in policy and practice. Perspectives on single-sex and coeducational schooling (s. 212-226). New York: Routledge.

\section{Autorka}

PhDr. Irena Smetáčková, Ph.D., Univerzita Karlova v Praze, Pedagogická fakulta, Katedra psychologie, Myslíkova 7, 11000 Praha 1, e-mail: irena.smetackova@pedf.cuni.cz 


\title{
Co-education or single-sex education?
}

\begin{abstract}
The article compares co-education and single-sex education. Based on international research, the positive and negative sides of both models are discussed. Focusing on gender equality, unreflected coeducation is found problematic because gender stereotypes are usually reproduced. The potential promotion of single-sex education in Czech Republic (following international experimental schools) should take into account students' opinions. The article brings the results of a survey $(\mathrm{N}=556)$ that was focused on students' approaches and experience with single-sex and co-education. Children prefer coeducational settings despite of reporting the gender biased peer harassment and the unequal treatment by teachers.
\end{abstract}

Keywords: coeducation, single-sex education, gender equality

Ježková, V., Walterová, E., Abankina, T., \& Abankina, I. (2013).Školní vzdělávání $v$ Ruské federaci. Praha: Karolinum.

Analyticko-srovnávací studie je čtvrtou publikací řady Školní vzdělávání v zahraničí. Předchozí tři publikace jsou Školní vzdělávání v Německu, Školní vzdělávání ve Velké Británii a Školní vzdělávání ve Švédsku. Část studie, vypracovaná českými autorkami, zprostředkuje na školní vzdělávání „pohled zvenku“, který lze považovat za „objektivní“, „neutrální“, pouze minimálně ovlivněný př́mými zkušenostmi. „Pohled zevnitř“" přináší závěrečná kapitola ruských spoluautorek. Těžiště studie tvoří problémy, které se jeví jako zásadní v ruském školním vzdělávání a jsou aktuální také pro rozvoj českého školního vzdělávání. Skládá z devíti kapitol. První kapitola uvádí do širšího kontextu země, v němž změny školního vzdělávání probíhají. Ve druhé kapitole, věnované vzdělávací politice, se pozornost obrací ke kodifikaci nového pojetí vzdělávání a vývoji legislativy od 90. let minulého století. Třetí kapitola posuzuje současný vzdělávací systém Ruska, orientuje v jeho diverzifikované struktuře a podstatných dimenzích, v nichž došlo k zásadním změnám. Obsahem čtvrté kapitoly jsou pedagogické experimenty, alternativní pedagogické koncepce a autorské školy. Pátá kapitola je věnována problematice kurikula s důrazem na federální vzdělávací standardy. Šestá kapitola seznamuje se systémem evaluace a problémy souvisejícími se zaváděním pro ruské prostředí netradičních forem a nástrojů hodnocení. Specifiky multinárodnostního ruského státu a jeho mnohojazyčné společnosti, která jsou pro Ruskou federaci př́značná a mají důsledky pro vzdělávací politiku a praxi, se zabývají kapitoly sedmá a osmá. V poslední, deváté kapitole dostávají prostor ruské autorky, prezentující vnitřní pohled na ruskou vzdělávací reformu. Studie je určena výzkumníkům a odborníkům v oblasti vzdělávání, vyučujícím i studentům pedagogických fakult a dalších fakult připravujících učitele, představitelům Ministerstva školství, mládeže a tělovýchovy České republiky i dalším pracovníkům působícím ve státní správě zabývajícím se vzděláváním. 